\title{
IDENTIFICATION OF CHERNOBYL FALL-OUT AS A NEW REFERENCE LEVEL IN NORTHERN HEMISPHERE GLACIERS
}

By M. Pourchet, J.F. Pinglot, L. Reynaud,

(Laboratoire de Glaciologie et Géophysique de l'Environnement du Centre National de la

Recherche Scientifique, 38402 Saint-Martin-d'Hères Cedex, France)

and $\mathrm{G}$. HoldsworTH

(National Hydrology Research Institute, 11 Innovation Boulevard, Saskatoon,

Saskatchewan S7N 3H5, Canada)

ABSTRACT. Among the various artificial radioactive markers (mainly from atmospheric nuclear tests), the contamination from the Chernobyl accident has been found at five sampling sites on Northern Hemisphere glaciers. Total beta-activity measurements reveal a very high radioactive level. However, due to the short time of its occurrence, the temporal resolution of this event in the snow layers can be generally quite low and positive results require careful sampling. The size of the signal also depends on the trajectory of the contaminant cloud, the amount of precipitation, and the surface conditions during deposition.

\section{INTRODUCTION}

Until now, the greatest amount of deposition of artificial radioactivity on temperate glaciers and polar ice sheets came from atmospheric thermonuclear tests.

A significant number of these tests contaminated the stratosphere, leading to the world-wide spread of radionuclides. These are found in the annual snow layers, giving rise to well-known reference levels, and thus allowing accurate snow dating in both Northern and Southern Hemisphere glaciers (Picciotto and others, 1963; Crozaz, 1969; Hammer and others, 1978).

The radioactive pollution of glaciers by the nuclear power industry generally presents a more local pattern. The following is a chronological list of the most important accidents, including the failures of nuclear reactor-powered satellites:

October 1957. The Windscale (U.K.) accident dispersed $20 \mathrm{kCi}$ of ${ }^{131} \mathrm{I}$ and $0.6 \mathrm{kCi}$ of ${ }^{137} \mathrm{Cs}$. The corresponding pollution may have reached the Alps, having been observed in West Germany, the Benelux countries, and Scandinavia (Gordon, 1979).

April 1964. The disintegration of the SNAP-9A satellite between 40 and $60 \mathrm{~km}$ altitude, at lat. $11^{\circ} \mathrm{S}$. over the Indian Ocean, dispersed $17 \mathrm{kCi}$ of ${ }^{238} \mathrm{Pu}$. By $1970,95 \%$ of this activity had been deposited on the Earth, leading in 1973 to a ${ }^{238} \mathrm{Pu}$ total amount deposited (in the

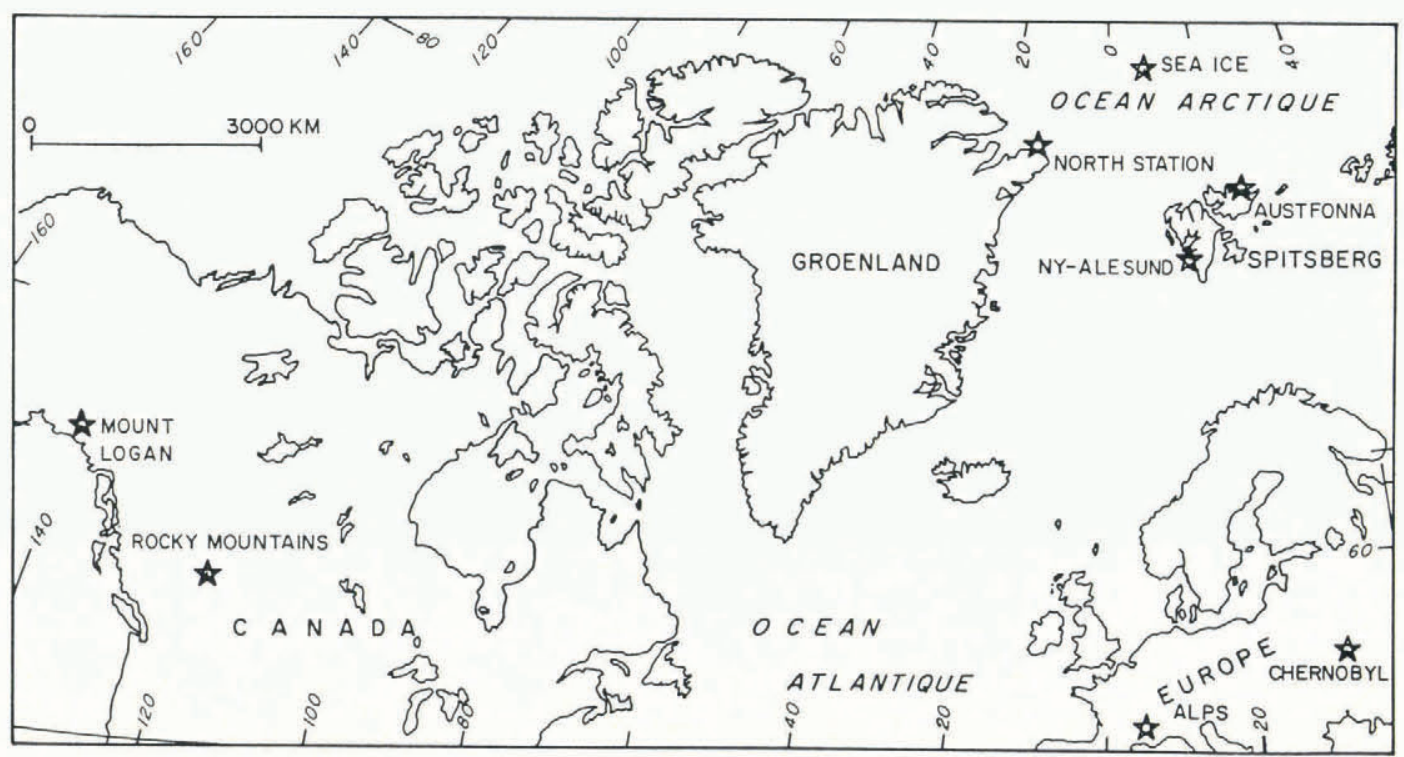

Fig. 1. Map of snow-sampling sites on Northern Hemisphere glaciers. 

TABLE I. BETA ACTIVITY OF SNOW SAMPLES WITH THEIR LOCATIONS AND DATES OF
COLLECTION

Location

Greenland

Station Nord
(lat. $81^{\circ} 36^{\prime} \mathrm{N}$., long. $16^{\circ} 40^{\prime} \mathrm{W}$.)

Sea Ice Station

(lat. $84^{\circ} 13^{\prime} \mathrm{N}$., long. $17^{\circ} 50^{\prime} \mathrm{E}$.)

Svalbard

Austfonna

(lat. $79^{\circ} 43^{\prime}$ N., long. $25^{\circ} 43^{\prime}$ W., $525 \mathrm{~m}$ )

Ny-Alesund

Alps

Aiguille du Midi (Mont Blanc area, $3842 \mathrm{~m}$ ) Col du Dôme (Mont Blanc area,
$4250 \mathrm{~m}$ )

Mont de Lans glacier (Ecrins area, $3300 \mathrm{~m}$ )

North America

Eclipse site

(lat. $60^{\circ} 50^{\prime} \mathrm{N}$., long. $139^{\circ} 50^{\prime} \mathrm{W}$., $3017 \mathrm{~m}$ )

Seward Glacier

(lat. $60^{\circ} 22^{\prime} \mathrm{N}$., long. $139^{\circ} 50^{\prime} \mathrm{W}$., $1830 \mathrm{~m}$ )

Mount Logan

(lat. $60^{\circ} 35^{\prime} \mathrm{N}$., long. $140^{\circ} 35^{\prime} \mathrm{W}$., $5340 \mathrm{~m}$ )

Snow Dome

(in the Rocky Mountains, Alberta, $3406 \mathrm{~m}$ )
Remarks

8 May snowfall

(13.00-19.00 h GMT)

12 May snow surface

(11 May snowfall)

12 May snow surface

(11 May snowfall)

4 May snow surface

(old deposition)

4 May snowfall

10-11 May snowfall

17-18 May snowfall

25 May snow surface

(after blowing snow)

8 May snow surface

(old deposition)

13 May snow surface

(after snowfall)

16 May snow surface

( $\sim 1$ month of deposition)

21 May snowfall

6 June snowfall

8 June snow surface

(0-40 cm depth)

2 December ice core

$(200-210 \mathrm{~cm})^{(1)}$

25 May ice core

$(0-20 \mathrm{~cm})^{(1)}$

$0.15^{(2)}$

$0.46^{(2)}$

$8.84^{(2)}$

$1.38^{(2)}$

$1.08^{(2)}$

0.59

3 June $1986^{(\mathrm{a})}$ January $1987^{(\mathrm{b})}$

$\mathrm{Bq} \mathrm{kg}^{-1}$

$0.38^{(2)}$

0.42

$1.33^{(2)}$

$0.05^{(2)}$

$0.15^{(2)}$

0.19

$8.78^{\text {(c) }} \quad 10.05$

$0.25^{\text {(c) }} \quad 0.27$

0.13

23.46

5.79

4.08

Summer 1986 ice core

$$
(80-100 \mathrm{~cm})^{(1)}
$$

Summer 1986 ice core $(100-120 \mathrm{~cm})^{(1)}$

Summer 1986 ice core $(30-60 \mathrm{~cm})^{(1)}$

9 November 1986 ice core

(1) Maximum observed value of radioactivity of snow layer which may correspond to Chernobyl; (a), (b), (c): counting dates ((c) is October 1986).

(2) Pourchet and others, 1986 (published 23 October 1986). 
Southern Hemisphere) of $12.4 \mathrm{kCi}$, composed of $10.8 \pm 2.1 \mathrm{kCi}$ from the satellite and $1.6 \pm 0.3 \mathrm{kCi}$ from thermonuclear tests (Hardy and others, 1973). This ${ }^{238} \mathrm{Pu}$ fall-out constitutes a chronological level in the Antarctic snow layers where the corresponding peak radioactivity values are as high as $1.5 \times 10^{-3} \mathrm{~Bq} \mathrm{~kg}^{-1}$ at Dome C (East Antarctic plateau) (Cutter and others, 1979).

January 1978. The Cosmos 954 satellite spread $50 \mathrm{~kg}$ of highly enriched uranium over northern Canada. This radionuclide has been identified in Greenland snow layers (Koïde and Golberg, 1983).

\section{CHERNOBYL FALL-OUT IN SNOW}

The Chernobyl accident (26 April 1986) (Pourchet and others, 1986) is of special concern in France, since the Chernobyl-dispersed ${ }^{137} \mathrm{Cs}$ deposited within the Alpine area (information to be published) represents $15 \%$ of the amount of the residual ${ }^{137} \mathrm{Cs}$ activity due to previous atmospheric nuclear tests.

Quantitative measurements of radioactive materials have been conducted on snow samples from several glaciers of the Northern Hemisphere: Greenland, Svalbard, North America, and the French Alps (Fig. 1). The snow samples, after melting and filtration (Delmas and Pourchet, 1977) were analysed for total beta activity using low-level counting equipment (Pinglot and Pourchet, 1979) and for gamma activity by spectrometry (using a specially designed low-background scintillation detector (Pinglot and Pourchet, 1981)) in order to identify the artificial radio-isotopes from the Chernobyl accident among the natural background radioactivity (short- or long-lived isotopes mainly from the decay products of uranium and thorium).

\section{SNOW-SAMPLING SITES}

\section{Freshly fallen snow}

The radioactive materials were mostly scavenged by the precipitation process and there was no dry deposition on the snow itself. Old snow (sampled on 8 May 1986 in $\mathrm{Ny}$ Alesund, Svalbard) was free of radioactivity, whereas the 10-11 May fresh snowfall at Austfonna was contaminated (Table I). The scavenging process was similar to that observed with wet precipitation (Fry and others, 1986); at the precise time of arrival of the Chernobyl pollution, as shown in Table $I$, the artificial radioactive levels show a great increase: $5.47,10.05$, and $4.08 \mathrm{~Bq} \mathrm{~kg}^{-1}$, respectively, in Austfonna, Aiguille du Midi (Mont Blanc area, $3800 \mathrm{~m}$ ), and Mont de Lans glacier (Ecrins area, $3300 \mathrm{~m}$ ) (Fig. 2).

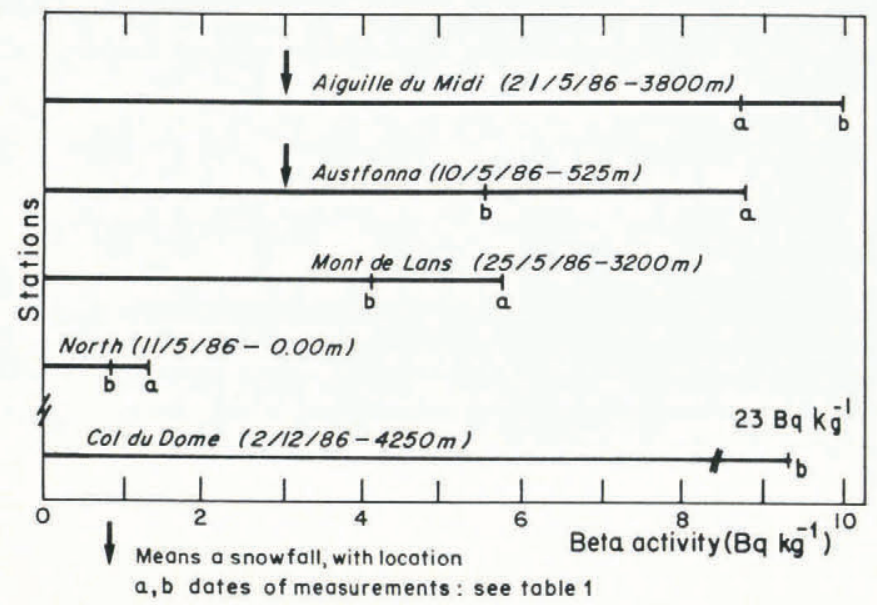

Fig. 2. Comparison of beta activity from several glaciers of the Northern Hemisphere.

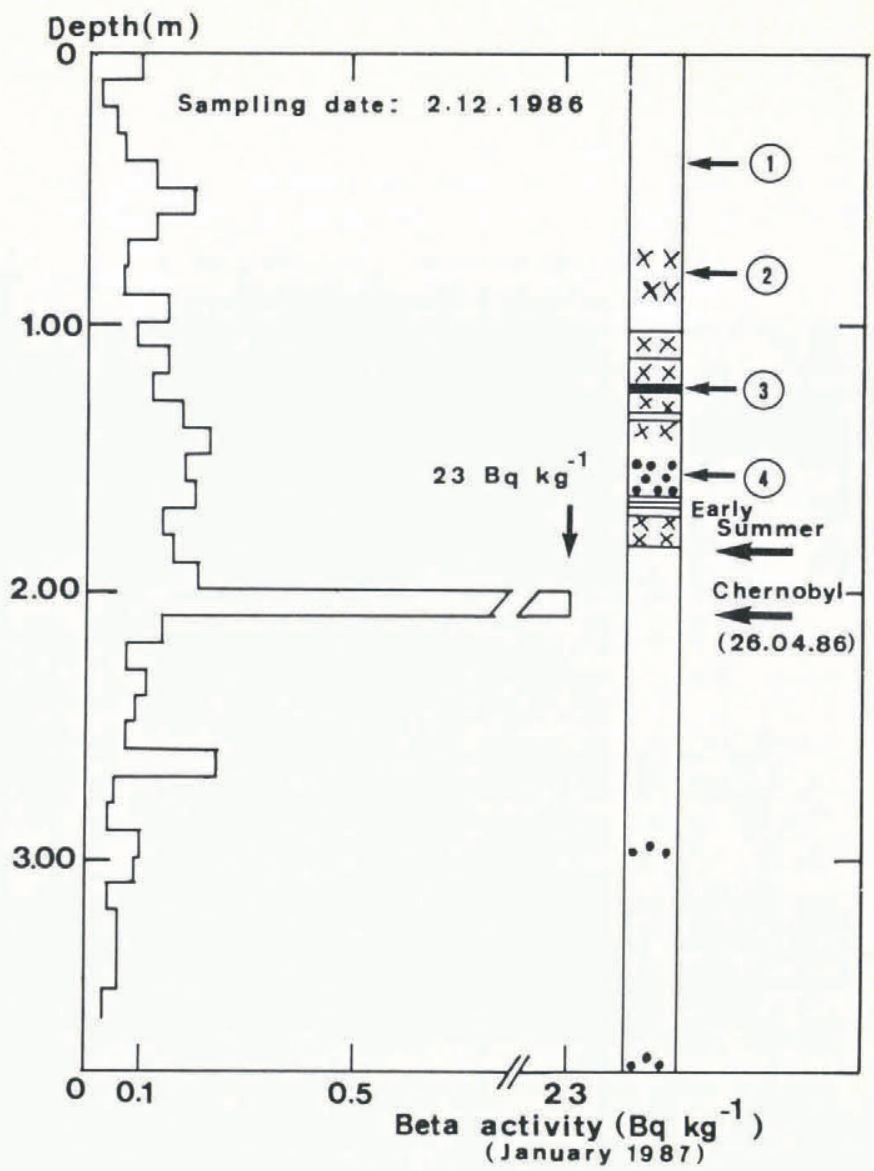

Fig. 3. Beta activity versus depth for Col du Dôme (Mont Blanc area, $4250 \mathrm{~m} ; 2$ December 1986 drilling; January 1987 measurements). (1) Small grain firn; (2) Rough firn; (3) Ice layer; (4) Ice lens.

\section{French Alps}

An ice core was drilled at Col du Dôme (Mont Blanc area, $4250 \mathrm{~m}$ ) on 2 December 1986. This core (Fig. 3) shows a narrow layer of much enhanced beta activity $\left(23 \mathrm{~Bq} \mathrm{~kg}^{-1}\right.$ ) between depths of 2.0 and $2.1 \mathrm{~m}$, clearly deeper than the relatively high levels of natural radioactivity which prevail each summer due to a reduced snowcover leading to the spreading of exposed soils by aeolian processes. The radioactivity peak is high compared to the previously measured values in the precipitation samples, despite the infrequent and light precipitation events in May 1986 , as recorded at the nearby meteorological station (Les Contamines-Montjoie) (Association Météorologique de la Haute-Savoie, 1986) (Fig. 4), in addition to a Nivose automatic snow-cover station (Plan de l'Aiguille du Midi, elevation: $2403 \mathrm{~m})$ (EERM/CEN, 1986). Based on the gamma-spectrometry measurements, the ${ }^{137} \mathrm{Cs}$ specific and deposited activities are respectively $10.4 \mathrm{~Bq} \mathrm{~kg}^{-1}$ and $538 \mathrm{~Bq} \mathrm{~m}^{-2}$ at the Col du Dôme station, which are in good agreement with the value determined on a sediment core

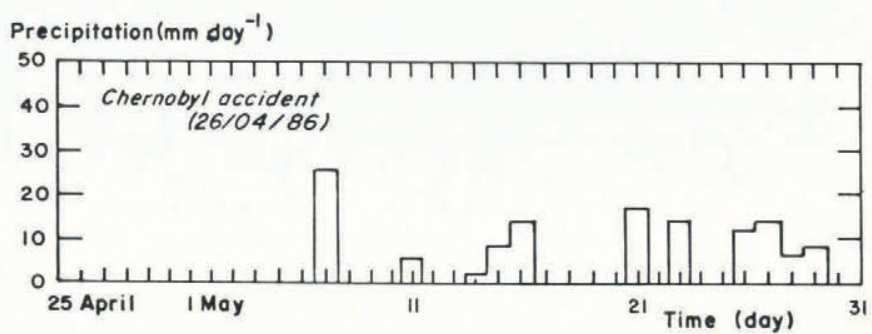

Fig. 4. Daily precipitation during April-May 1986 at Les Contamines-Mont joie meteorological station (Haute-Savoie. $1180 \mathrm{~m})$. 
from the nearby lake Lériè $\left(420 \mathrm{~Bq} \mathrm{~m}^{-2}\right)$ (Mélières and others, in press), and the value from the Mont de Lans glacier ice core $\left(200 \mathrm{~Bq} \mathrm{~m}^{-2}\right)$, as discussed below.

A second ice core drilled on 25 May 1986 in Mont de Lans glacier (Ecrins area, $3300 \mathrm{~m}$ ) clearly exhibits a very strong radioactive level due to the Chernobyl fall-out. This level $\left(4.08 \mathrm{~Bq} \mathrm{~kg}^{-1}\right)$ is of the same order as that detected in the Col du Dome ice core $\left(23 \mathrm{~Bq} \mathrm{k}^{-1}\right)$. Due to the lower elevation of the temperate Mont de Lans glacier, melting and percolation occur, diffusing the Chernobyl layer down to a depth of $1.2 \mathrm{~m}$ (Fig. 5). As noted above, the ${ }^{137} \mathrm{Cs}$ deposited activity is $200 \mathrm{~Bq} \mathrm{~m}^{-2}$, with a specific activity of

\section{$\operatorname{Depth}(m)$}

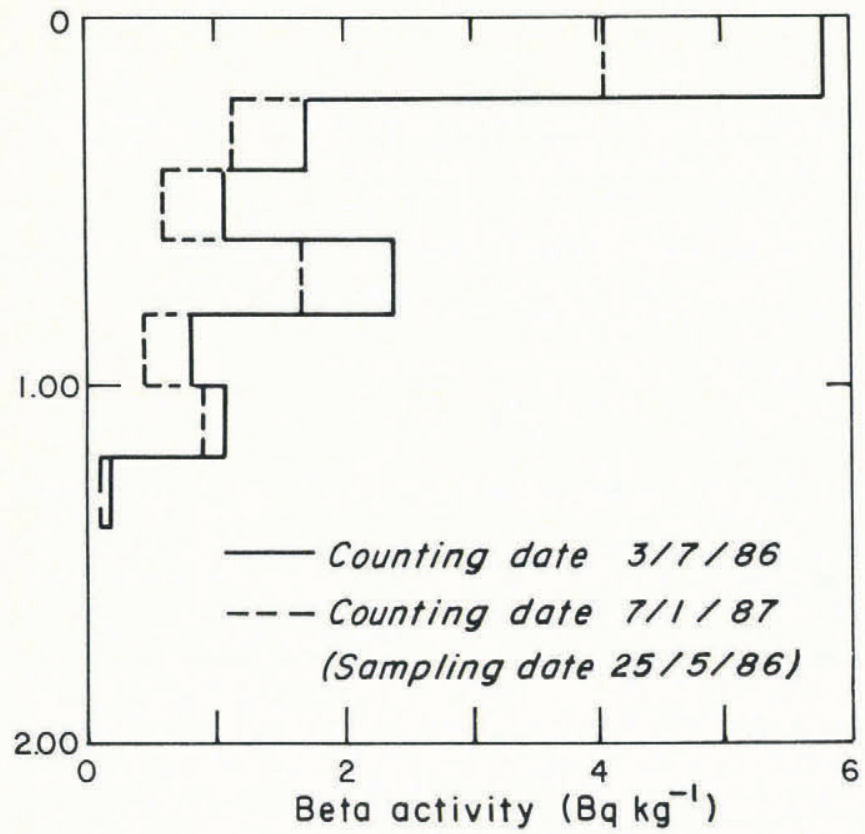

Fig. 5. Beta activity versus depth for an ice core from Mont de Lans glacier (Ecrins area, $3300 \mathrm{~m}$; 25 May 1986 drilling).

$1.76 \mathrm{~Bq} \mathrm{~kg}^{-1}$. Chernobyl fall-out is also well marked $\left(2 \mathrm{~Bq} \mathrm{~kg}^{-1}\right)$ in another ice core, drilled in the summer of 1987 at Col des Ecrins-Glacier Blanc (Ecrins area, $3300 \mathrm{~m}$ ) for snow-accumulation determination.

\section{North America}

Other snow samples were collected in the summers of 1986 and 1987 in North America (Rocky Mountains, $3460 \mathrm{~m}$; Mount Logan, Canada, $5340 \mathrm{~m}$ ). Although air samples had reflected the Chernobyl accident (Gilbert, 1986), beta activity in the snow did not significantly exceed the natural radioactivity levels found at the five different sites. Samples of a greater weight should have been used to obtain a more accurate radioactive signal from Chernobyl. Moreover, these samples should have been subjected to a highly sensitive gamma-ray spectrometer, in order to identify the specific isotopes from Chernobyl.

\section{DISCUSSION}

The radioactivity increase shows an extensive and variable spatial distribution, including a large range of altitudes (from sea-level in Svalbard up to $5340 \mathrm{~m}$ on Mount Logan) and latitudes (from about lat. $45^{\circ}$ to $90^{\circ} \mathrm{N}$.) (Ambach and others, 1987; Davidson and others, 1987; Haeberli and others, 1988). This increase in total beta activity reached about 100 times the level of freshly deposited natural snow. Radioactive fall-out levels are highly dependent on the amount of precipitation and on the wind conditions, as shown by the Col du Dome profile, and possibly the Mount Logan snow.
Surface conditions also lead to irregularities in the radioactivity profile (melting, wind scouring, etc.) Therefore, identification of the Chernobyl layer requires close sample spacing along each ice core.

The samples from several stations were combined for identification of ${ }^{137} \mathrm{Cs}$ and ${ }^{134} \mathrm{Cs}$ by gamma spectrometry (sensitivity of about $0.04 \mathrm{~Bq}$ ) and for determination of the activity of each element deposited.

Moreover, these measurements led to the quantitative detection of ${ }^{134} \mathrm{Cs}$ and ${ }^{137} \mathrm{Cs}$, among other isotopes, except in the North American samples. A subsequent decrease in radioactivity (as described by Picciotto and others (1971); (Table I, Figs 2-5)) has been observed for most Chernobylcontaminated samples, except the snowfall from Aiguille du Midi (21 May 1986, $3800 \mathrm{~m}$ ) (see Fig. 2); no clear interpretation can be given.

Despite this decrease, the ${ }^{137} \mathrm{Cs}$ activity (half life: 29.5 years) will still be a useful well-known level in snow at locations where Chernobyl fall-out occurred.

\section{CONCLUSION}

The Chernobyl accident gave rise to a very strong radioactive level in the snow deposited in Greenland, Svalbard, and the Alps. This new radioactivity peak is therefore suitable for dating the snow layers. However, the temporal resolution of this event is quite low and depends on the amounts of precipitation and surface conditions.

In North America, the detection of this new artificial radioactivity reference level will require snow samples of greater weights.

\section{ACKNOWLEDGEMENTS}

Samples from Greenland were provided by Femmes pour un Póle and Arctemiz, and those from Svalbard by C. Rado and M. Vallon from the Laboratoire de Glaciologie et Géophysique de l'Environnement. The French Civil Defence kindly provided helicopter transport to the Col du Dôme du Goûter. Logistic and field work from Parc National des Ecrins was much appreciated.

\section{REFERENCES}

Ambach, W., Rehwald, W., Blumthaler, M., and Eisner, H. 1987. Chernobyl fallout on Alpine glaciers: a new reference horizon for dating. EOS, 68(45), 1577.

Association Metéorologique de la Haute-Savoie. 1986. Bulletin Climatologique Mensuel, 24.

Crozaz, G. 1969. Fission products in Antarctic snow, an additional reference level in January 1965. Earth and Planetary Science Letters, 6(1), 6-8.

Cutter, G.A., Bruland, K.W., and Risebrough, R.W. 1979. Deposition and accumulation of plutonium isotopes in Antarctica. Nature, 279(5714), 628-29.

Davidson, C.I., Harrington, J.R., Stephenson, M.J., Monaghan, M.C., Pudykiewicz, J., and Schell, W.R. 1987. Radioactive cesium from the Chernobyl accident in the Greenland ice sheet. Science, 237(4815), 633-34.

Delmas, R., and Pourchet, M. 1977. Utilisation de filtres échangeurs d'ions pour l'étude de l'activité $B$ globale d'un carottage glaciologique. International Association of Hydrological Sciences Publication 118 (General Assembly of Grenoble 1975 - Isotopes and Impurities in Snow and Ice), 159-63.

EERM/CEN. 1986. La neige et les avalanches dans les Alpes, les Pyrénées et la Corse, hiver 1985-1986. Boulogne, Établissement d'Études et de Recherches Météorologiques. Centre d'Étude de la Neige.

Fry, F.A., Clarke, R.H., and O'Riordan, M.C. 1986. Early estimates of UK radiation doses from the Chernobyl reactor. Nature, 321(6067), 193-95.

Gilbert, R. 1986. Sur les traces de Tchernobyl. Milieux, 33, $6-10$ 
Gordon, E. 1979. Incidents et accidents nucléaires. Sciences et Avenir, 27, 32-37.

Haeberli, W., Găggeler, H., Baltensperger, U., Jost, D., and Schotterer, U. 1988. The signal from the Chernobyl accident in high-altitude firn areas of the Swiss Alps. Annals of Glaciology, 10, 48-51.

Hammer, C.U., Clausen, H.B., Dansgaard, W., Gundestrup, N., Johnsen, S.J., and Reeh, N. 1978. Dating of Greenland ice cores by flow models, isotopes, volcanic debris, and continental dust. Journal of Glaciology, 20(82), 3-26.

Hardy, E.P., Krey, P.W., and Volchok, H.L. 1973. Global inventory and distribution of fallout plutonium. Nature, 241(5390), 444-45.

Koide, M., and Goldberg, E.D. 1983. Uranium isotopes in the Greenland ice-sheet. Earth and Planetary Science Letters, 65(2), 245-48.

Mélières, M.A., Pourchet, M., Pinglot, J.F., and Bouchez, R. In press. Chernobyl ${ }^{134} \mathrm{Cs},{ }^{137} \mathrm{Cs}$ and ${ }^{210} \mathrm{~Pb}$ in high mountain lake sediment: measurements and modelling of mixing process. Journal of Geophysical Research.
Picciotto, E., and Wilgain, S. 1963. Fission products in Antarctic snow, a reference level for measuring accumulation. Journal of Geophysical Research, 68(21), 5965-72.

Picciotto, E., Crozaz, G., and Breuck, W. de. 1971. Accumulation on the South Pole-Queen Maud Land Traverse, 1964-1968. In Crary, A.P., ed. Antarctic snow aned ice studies II. Washington, DC, American Geophysical Union, 257-315. (Antarctic Research Series,16.)

Pinglot, J.F., and Pourchet, M. 1979. Low-level beta counting with an automatic sample changer. Nuclear Instruments and Methods, 166(3), 483-90.

Pinglot, J.F., and Pourchet, M. 1981. Gamma-ray bore-hole logging for determining radioactive fallout layers in snow. In Methods of Low-Level Counting and Spectrometry. Proceedings of an International Symposium ... Berlin (West), 6-10 April 1981. Vienna, International Atomic Energy Agency, 161-72. (Proceedings Series.)

Pourchet, M., Pinglot, J.F., and Gascard, J.C. 1986. The northerly extent of Chernobyl contamination. Nature, $323(6090), 676$. 